\title{
Preliminary Reference Values of Serum Sarcosine, Prostate Specific Antigens And Testosterone in Apparently Healthy Males in Sokoto, Nigeria.
}

\author{
${ }^{* 1}$ Nnamah,NK,${ }^{2}$ Anaja, PO, ${ }^{3}$ Mungadi, IA, ${ }^{4}$ Bilbis,LS, And ${ }^{5}$ Dallatu,MK \\ ${ }^{I}$ Department Of Chemical Pathology, Faculty Of Allied Health Sciences, Nnamdi Azikwe University, Nnewi, \\ ${ }^{2}$ Department Of Chemical Pathology, Faculty Of Medicine, Ahmadu Bello University, Zaria, \\ ${ }^{3}$ Department Of Surgery, Faculty Of Clinical Sciences, Usmanu Danfodiyo University,Sokoto, \\ ${ }^{4}$ Department Of Biochemistry, Faculty Of Science, Usmanu Danfodiyo University, Sokoto, \\ ${ }^{5}$ Department Of Chemical Pathology, Faculty Of Medical Laboratory Science, Usmanu Danfodiyo University, \\ Sokoto, Nigeria
}

\begin{abstract}
:
Background: Detailed knowledge about specific metabolic pathways and molecular mechanisms involved in the development and pathogenesis of prostate disorders are still incomplete.To decide the presence or absence of disease, a cut-off point is chosen for data interpretation. In the current work, we reported the preliminary reference values for panel of biomarkers from healthy Nigerians to aid diagnosis of prostate disorders.

Methods: Whole blood was collected from 399 healthy Nigerians men between the ages of 30-70 years. Serum sarcosine, testosterone, and various derivatives of PSA were evaluated using standard procedures.

Results: Our results showed that, in between the age bracket of 30-40 years (lowest), serum sarcosine value range was 54.57-77.55 $\mathrm{ng} / \mathrm{dl}$, total testosterone $3.76-8.00 \mathrm{ng} / \mathrm{ml}$, free testosterone $7.13-16.33 \mathrm{ng} / \mathrm{ml}$, total PSA 0.6-4.48 ng/ml, free PSA 0.30-1.09 $\mathrm{ng} / \mathrm{ml}$, complex PSA 0.4-3.92 $\mathrm{ng} / \mathrm{ml}$,\% free PSA 18.90-39.90, \% complex PSA 57.10-84.10. In between the age bracket of 60-70 years (highest) serum sarcosine value ranges 44.84$77.26 \mathrm{ng} / \mathrm{dl}$, total testosterone $3.68-5.12 \mathrm{ng} / \mathrm{ml}$, free testosterone $5.82-11.84 \mathrm{ng} / \mathrm{ml}$, total PSA 1.97-3.66 $\mathrm{ng} / \mathrm{ml}$, free PSA 1.97-3.66 ng/ml, complex PSA 1.22-2.88 ng/ml, \% free PSA 14.65-37.13, \% complex PSA 63.71-85.35.

Conclusion: This is first of such study to establish reference values for these biomarkers of prostate disorders hence underscored the need to establish reference values for different populations.
\end{abstract}

\section{Introduction}

Clinical laboratory tests are useful for diagnosing health disorders, drug toxicity or side effects, disease staging and monitoring of response to treatment. Additionally, interpretation of laboratory test results with appropriate diagnostic accuracy must be based on reference or cutoff values ${ }^{1}$. In Nigeria and many developing countries, values are derived largely from other developed countries, solely because must diagnostic kits and reagents are imported from such countries ${ }^{2}$.

The usual ranges for most prostate disorders were derived from a community-based population of white men, ${ }^{3}$ but they were used for screening on all men on the assumption that the differences in their levels at different racial groups are either small or not clinically significant ${ }^{4}$. Black men in the United States have one of the highest prostate cancer rates worldwide and have a 50\% higher age-adjusted incidence of prostate cancer than white men ${ }^{4}$.Asian men have the lowest rates of prostate cancer, and there may be as much as a 120 -fold difference between rate of prostate cancer in the lowest risk group (Shanghai, China) and the highest risk group (black men in San Francisco, California) ${ }^{3}$. With differences in Geographical locations, climate, dietary habits, and environmental factors or ethnic and tribal peculiarities, need for development of these important reference values is critical.

Prostate disorders such as cancer of the prostate $(\mathrm{CaP})$ and benign prostatic hyperplasia $(\mathrm{BPH})$ are some of these disorders usually misdiagnosed or misstaged, leading to avoidable biopsies and treatment overload $^{5}$. Correct diagnosis of prostate disorders ultimately is based on measurement of dependable biomarkers. However, marked variations in reference ranges among laboratories posed a challenge to clinician when interpreting the results ${ }^{6}$.These suggest that the development of reference values for local population is critical for interpretation of laboratory results and provision of quality services in the Health care delivery.

In the current study, we reported the preliminary reference values of some biomarkers for prostate disorders that may be required for the proper data interpretation of these prostate biomarkers in our localities. 


\section{Materials and Methods}

Consented clients were clinically screened and counselled at the Urology Unit, Usmanu Danfodiyo University Teaching Hospital Sokoto before enrolment. Standard questionnaire capturing demographic data, medical status, history and social habit of each participants was administered to the consented participants and 399 volunteers were qualified to be used in the study. Institutional ethical approval was obtained from Ethical committee of the Hospital before the study commenced. Serum sarcosine was measured by the colourimetric method (BioVision Research Products, 980 Linda Vista Avenue, Mountain View, CA 94043 USA). Serum total and free Testosterone were estimated using Enzyme Linked Immunoassay (ELISA) ${ }^{7}$. Total and free Prostate Specific Antigen (tPSA,fPSA) were estimated by Elisa method ${ }^{8}$ while complexed Prostate Specific Antigen (cPSA) was calculated mathematically by the formula: cPSA = Total PSA - (fPSA).

\section{Results}

Results of the current study were shown on tables 1 and 2.Table 1shows mean and range of serum sarcosine, total and free testosterone, while table 2 shows mean and ranges of PSA derivatives studied.

\section{Discussion}

We reported here, baseline values of serum biomarkers that are used in the diagnosis and prognosis of prostate disorders in our locality and the analytes studied here hold significant diagnostic and prognostic values. To the best of our knowledge, no study of this type was conducted here, hence aimed at providing a baseline that can serve as a preliminary.

Many studies led to interest in sarcosine as a prostate cancer biomarker but in many of such studies, results have been conflicting; some indicated higher risk associated with higher levels of sarcosine and others, a lower risk ${ }^{9,10}$. In order to definitively assess the potential of serum sarcosine for further study, we are reporting a preliminary data for its reference value in our locality.

Testosterone play significant role in prostate disorders. Testosterone is an important growth factor for prostate cells. If testosterone availability drops, prostate cells stop thriving. Benign prostate shrinks and the same happens with prostate cancer cells ${ }^{11}$. Larger decrease in testosterone availability means larger reduction in prostate cells mass. Although only reduction in testosterone levels will not, in most occasions, permanently heal prostate cancer, it causes its regression and significantly delays further progression of prostate cancer. Therefore, reduction of body's testosterone level is important prostate cancer treatment modality ${ }^{12}$. When surgical removal of prostate due to cancer is not an opinion (for example because of advanced age, significant co morbidity or because cancer has already spread beyond prostate) or was unsuccessful as noted by rising PSA, which indicates cancer growth, serum testosterone value becomes very important factor in treatment related decisions. If testosterone values are high, reduction of testosterone level will be helpful - it is expected prostate cells will react, shrink and PSA level will fall. If testosterone values are already low, their further reduction with different agent may be possible. If testosterone values are already at the lowest reachable levels, other ways of treatment should be sought. After reduction of testosterone levels in the body (castration), prostate cancer cells with time (sometimes months, sometimes years, sometimes decades) develop alternative signaling mechanisms and ways of paracrine androgens supply. It is estimated that this happens in a third of all prostate cancer patients $^{13}$.

For serum PSA, it was reported that it is organ specific, not carcinoma specific. Serum PSA can be elevated due to a number of reasons such as prostatic manipulation, inflammation, urinary retention, sexual activity among others ${ }^{14}$. More recent data provide evidence of the exclusion of unacceptably high number of patients with clinically organ confined cancer when a single reference range was applied indiscriminately to different populations ${ }^{15}$.To us, one major concept to ensure the discriminatory power of PSA is to establish age specific reference ranges for local population.

The reasons for the observed values are still unclear and hence additional studies needed, but may be due to diet, genetic factors or other environmental factors. This underscores the need to establish reference ranges of local populations and additional studies to confirm these interesting findings

The establishment of appropriate reference ranges for serum sarcosine, testosterones and various PSA derivatives will allow the practicing urologist in our localities to incorporate these new parameters into diagnostic evaluation of men at risk for early, potentially curable prostate disorders. The preliminary data here provided will awaken the scientific community on the need for further work in the area to address this diagnostic challenges.

\section{References}

[1]. Timzing Miri-Dashe,Sophia Osawe1, Monday Tokdung , Nenbammun Daniel, Rahila Pam Choji , Ille Mamman, Kurt Deme , Dapus Damulak, Alash'le Abimiku (2014).Comprehensive Reference Ranges for Hematology and Clinical Chemistry Laboratory Parameters Derived from Normal Nigerian Adults. PLoS ONE 9(5):1-10. 
[2]. Saathoff E, Schneider,P, Kleinfeldt,V, Geis, S, Haule, D. (2008). Laboratory reference values for healthy adults from southern Tanzania. Trop Med. Int. Health.13(5): 612-25.

[3]. Osterling JE et al(1993). Serum prostate-specific antigen in a community-based population of healthy men: establishment of agespecific reference ranges. JAMA; 270: 860-864.

[4]. Sawyer R, Berman JJ, Borkowski A, William MG.( 1996). Elevated prostate-specific antigen levels in black men and white men. Mod Pathol; 9: 1029-1032.

[5]. Jun, HL Yooseok, K. Yeon WP and Dong-Gi, L.( 2014). Relationship Between Benign Prostatic Hyperplasia/Lower Urinary Tract Symptoms and Total Serum Testosterone Level in Healthy Middle-Aged Eugonadal Men J. Sex. Med. 11: 1309-1315,

[6]. Wang, C. (2007). Challenges in the Diagnosis of the Right Patient for Testosterone Replacement Therapy. Eur. Urol. Suppl. 6:17. $862-867$.

[7]. Tietz, N.W. (1995). Testosterone, In: Clinical Guide to Laboratory Test, $3^{\text {rd }}$ Edition. Pp578-580. WB Saunders Coy.

[8]. Stowell,LH, Sharman,LE and Hamel, K.(1991).An enzyme-linked Immunosorbent Assay (ELISA) for prostate specific antigen. Forensic Science Intern.50:125-138.

[9]. de Vogel S, Ulvik A, Meyer K, Ueland PM, Nygard O, Vollset SE, et al.( 2014). Sarcosine and other metabolites along the choline oxidation pathway in relation to prostate cancer-a large nested case-control study within the JANUS cohort in Norway. Int $\mathbf{J}$ Cancer.;134(1):197-206.

[10]. Koutros S, Meyer TE, Fox SD, Issaq HJ, Veenstra TD, Huang WY, et al.( 2013). Prospective evaluation of serum sarcosine and risk of prostate cancer in the Prostate, Lung, Colorectal and Ovarian Cancer Screening Trial. Carcinogenesis.34(10):2281-5.

[11]. Mottet N, Bellmunt J, Bolla M, Joniau S, Mason M, Matveev V. (2011). EAU guidelines on prostate cancer. Part II: Treatment of advanced, relapsing, and castration-resistant prostate cancer. Eur. Urol.;59(4):572-83.

[12]. Peyromaure M, Rebillard X, Ruffion A, Salomon L, Villers A, Soulie M.( 2008) Time-course of plasma testosterone in patients with prostate cancer treated by endocrine therapy. Prog. Urol.18(1):2-8.

[13]. Bianco FJ Jr.( 2008). Paradigms in androgen/castrate resistant states of prostate cancer in a biomarker era. Urol. Oncol.;26(4):40814.

[14]. Carter, HB and Partin, AW (2002). Diagnosis and staging of prostate cancer.Chapter 88.In: Walsh PC, Retik,AB Vaughan,ED, Wein,AJ. Campbell's Urology. $8^{\text {th }}$ edition,Philiadelphia:Saunders;p. 3005-79

[15]. (Thompson,IM,Goodman,PJ,Tangen,CM et al (2003).The influence of finasteride on the development of prostate cancer.N.E.J.M;349:215-24.

Table 1 Defined reference ranges using the control subjects (Apparently healthy men) for Blood Sarcosine and Testosterones

\begin{tabular}{|c|c|c|c|c|c|c|}
\hline & \multicolumn{2}{|c|}{$\begin{array}{l}\text { TTesto } \\
(\mathrm{ng} / \mathrm{ml})\end{array}$} & \multicolumn{2}{|c|}{$\begin{array}{l}\text { FTesto } \\
(\mathrm{ng} / \mathrm{ml})\end{array}$} & \multicolumn{2}{|c|}{$\begin{array}{l}\text { Blood Sarcosine } \\
(\mathrm{ng} / \mathrm{dl})\end{array}$} \\
\hline & Mean & Range & Mean & Range & Mean & Range \\
\hline $\begin{array}{l}\text { CONTROLS } \\
(40-60 Y R S)(n=200)\end{array}$ & 5.72 & $3.74-7.70$ & 11.73 & $7.13-16.33$ & 64.94 & $53-77.41$ \\
\hline $\begin{array}{l}\text { CONTROLS } \\
(30-40 \text { YRS })(n=106)\end{array}$ & 5.88 & $3.76-8.00$ & 12.18 & $7.25-16.71$ & 66.02 & $54.57-77.55$ \\
\hline $\begin{array}{l}\text { CONTROLS } \\
(41-50 Y R S)(n=55)\end{array}$ & 5.64 & $3.76-7.42$ & 11.79 & $7.59-16.19$ & 62.93 & $52.64-73.22$ \\
\hline $\begin{array}{l}\text { CONTROLS } \\
(51-60 Y R S)(n=27)\end{array}$ & 5.71 & $3.62-7.80$ & 9.08 & $3.29-14.87$ & 67.93 & $56.71-79.15$ \\
\hline $\begin{array}{l}\text { CONTROLS } \\
(61-70 Y R S)(n=11)\end{array}$ & 4.40 & $3.68-5.12$ & 8.83 & $5.82-11.84$ & 55.55 & $44.84-77.26$ \\
\hline
\end{tabular}

Values are mean and ranges of Ttesto, Ftesto and sarcocine in the studied subjects.

Table 2 Defined reference ranges using the control subjects (Apparently healthy men) for PSA and their iso forms

\begin{tabular}{|c|c|c|c|c|c|c|c|c|c|c|}
\hline & \multicolumn{2}{|c|}{$\operatorname{tPSA}(\mathrm{ng} / \mathrm{ml})$} & \multicolumn{2}{|c|}{$\begin{array}{l}\text { Fpsa } \\
\text { (ng/ml) }\end{array}$} & \multicolumn{2}{|c|}{$\begin{array}{l}\text { Cpsa } \\
\text { (ng/ml) }\end{array}$} & \multicolumn{2}{|c|}{$\%$ fPSA } & \multicolumn{2}{|c|}{$\% \mathrm{cPSA}$} \\
\hline & Mean & Range & Mean & Range & $\begin{array}{l}\text { Mea } \\
\mathrm{n}\end{array}$ & Range & Mean & Range & Mean & Range \\
\hline $\begin{array}{l}\text { CONTROLS } \\
(40-60 \text { YRS }) \\
(\mathrm{n}=200)\end{array}$ & 2.75 & $0-5.77$ & 0.72 & $0.35-1.09$ & 2.03 & $0.90-4.96$ & 29.62 & $16.78-42.46$ & 70.38 & $57.53-83.21$ \\
\hline $\begin{array}{l}\text { CONTROLS } \\
(30-40 Y R S) \\
(\mathrm{n}=106)\end{array}$ & 2.28 & $0.6-4.48$ & 0.70 & 0.30-1.09 & 2.12 & $0.4-3.92$ & 29.40 & $18.90-39.90$ & 70.60 & $57.10-84.10$ \\
\hline $\begin{array}{l}\text { CONTROLS } \\
(41-50 \text { YRS }) \\
(\mathrm{n}=55)\end{array}$ & 2.62 & $1.46-3.78$ & 0.76 & $0.4-1.12$ & 1.86 & $0.86-2.86$ & 30.57 & $18.55-42.59$ & 69.43 & $57.41-81.45$ \\
\hline $\begin{array}{l}\text { CONTROLS } \\
(51-60 \text { YRS }) \\
(\mathrm{n}=27)\end{array}$ & 2.79 & $1.57-4.01$ & 0.76 & $0.40-1.11$ & 2.03 & $0.96-3.10$ & 29.30 & $19.00-39.45$ & 70.70 & $58.35-83.05$ \\
\hline $\begin{array}{l}\text { CONTROLS } \\
(61-70 Y R S) \\
(\mathrm{n}=11) \\
\end{array}$ & 2.76 & $1.97-3.66$ & 2.76 & $1.97-3.66$ & 2.08 & $1.22-2.88$ & 25.94 & $14.65-37.13$ & 74.06 & $63.71-85.35$ \\
\hline
\end{tabular}

Values are mean and ranges of tPSA, fPSA,cPSA,\%PSA and \% cPSA in the studied subjects 